\title{
Mother as Trope in Feminist Legal Theory
}

\author{
Mothers in Law: Feminist Theory and the Legal Regulation of Motherhood. \\ Edited by Martha Albertson Fineman and Isabel Karpin.** New York: \\ Columbia University Press, 1995. Pp. xiii, 398. $\$ 65.00$ (hbk.); $\$ 16.50$ (pbk.).
}

Until Martha Fineman and Isabel Karpin published their collection of essays, feminist scholars in law had largely ignored motherhood as a topic for discussion. To be sure, feminist scholars in other disciplines had embraced motherhood as a rich theoretical construct. ${ }^{\prime}$ By contrast, however, to the extent that feminist legal scholars had confronted motherhood, they had done so largely as a biological problematic: Should women's reproductive capacity garner women treatment that is different from or the same as men's? ${ }^{2}$

This focus on motherhood merely as an indicator of biological difference stems from feminist lawyers' strategic efforts to obtain equality for women in the late 1970s and 1980s: Feminist lawyers fought for and won judicial recognition of sex equality by styling women as the same as men. ${ }^{3}$ But women's capacity for motherhood, because it signals difference, challenges this

* Maurice T. Moore Professor of Law, Columbia Law School.

** Lecturer in Law, University of Sydney.

1. See, e.g., Nancy ChOdoROW, The ReProduction of MOTHERING 9 (1978) (arguing that "women's mothering is a central and defining feature of the social organization of gender and is implicated in the construction and reproduction of male dominance itself"); ADRIENNE RICH, OF WOMAN BORN: MOTHERHOOD AS EXPERIENCE AND INSTITUTION 13 (1976) (distinguishing social institution of motherhood from women's experience of motherhood).

2. See Martha Albertson Fineman, The Neutered Mother, The SeXual Family and Other TWENTIETH CENTURY TRAGEDIES 39 (1995). For examples of feminists' focus on reproductive capacity, see Lucinda M. Finley, Transcending Equality Theory: A Way Out of the Maternity and the Workplace Debate, 86 CoLUM. L. REV. 1118, 1143-44 (1986) (noting that law penalizes working mothers both by treating them like men and by treating them differently from men); Sylvia Law, Rethinking Sex and the Constitution, 132 U. PA. L. REv. 955, 1008-09 (1984) (arguing that classifications based on biological difference are permissible so long as they do not subordinate women to men); Wendy Williams, The Equality Crisis, 7 WOMEN's RTS. L. REP. 175, 194-95 (1982) (explaining split in feminist opinions regarding Pregnancy Discrimination Act, which requires employers to treat pregnancy as a compensable physical disability). But see Carmel B. Sella. When a Mother Is a Legal Stranger to Her Child: The Law's Challenge to the Lesbian Nonbiological Mother. 1 UCLA WOMEN's L.J. 135, 140 (1991) (ignoring sameness/difference debate in order to discuss specific concerns of lesbian mothers).

3. See David Cole, Strategies of Difference: Litigating for Women's Rights in a Man's World, 2 LAW \& INEQ. J. 33, 36-37 (1984). For examples of cases won using this sameness logic, see Mississippi University for Women v. Hogan, 458 U.S. 718 (1982) (requiring women-only nursing school to admit men because Court viewed challenged sex segregation as indicative of outmoded notions of women's roles); Craig v. Boren, 429 U.S. 190 (1976) (rejecting statutory prohibition against sale of $3.2 \%$ beer to boys younger than 21 years as invidious gender discrimination because girls older than 18 years could purchase beer). 
effort to prove sameness. Feminist legal theorists consequently divided for a period over the problem of sameness and difference. ${ }^{4}$

More recently, however, feminist legal scholars have begun to look beyond the equal treatment debate; they have begun to describe differences among women themselves and so to theorize about these differences rather than dwelling exclusively on equity with men. ${ }^{5}$ This newest "intersectional" focus in feminist legal theory examines women not as essential and univocal, but as differently classed, raced, and sexualized. ${ }^{6}$ According to this view, the various systems of subordination previously identified by separate feminist, critical race, and critical legal studies theories in fact intersect to subordinate women, as well as people of color, poor people, and lesbians and gay men in a particularly debilitating manner. ${ }^{7}$

The newfound variousness within the feminist rubric now offers feminist legal scholars the opportunity to confront motherhood less inhibited by concern that motherhood-and, more specifically, the biological difference that motherhood represents - undermines feminist legal goals. Martha Fineman and Isabel Karpin's collection of essays accepts the challenge, ${ }^{8}$ eschewing merely biological discussions of reproductive capacity in favor of attention to motherhood as one form of women's social plurality. As a result, the essays document and define a new diversity and complexity of feminist goals. In the process of offering theories of motherhood, prescriptions for mothering practice, and broadened perspectives on feminism, the essays reject the cultural presumption that all women are in some sense mothers whether or not they in

4. See Finley, supra note 2, at 1121; Introduction to AFTER IDENTITY: A READER IN LAW AND CULTURE at xiv (Dan Danielsen \& Karen Engle eds., 1995); Introduction to FEMINIST Legal THEORY: READINGS IN LAW AND GENDER 1 (Katharine T. Bartlett \& Rosanne Kennedy eds., 1991).

5. Although still articulating feminist legal theory largely in opposition to men, Catharine MacKinnon nonetheless initiated efforts to extricate legal feminists from the sameness/difference quagmire. MacKinnon argued that the equality debate failed women because it consistently privileged men as the norm rather than recognizing men and women as equally different from each other. See, e.g., CATHARINE A. MACKINNON, Difference and Dominance: On Sex Discrimination, in FEMINISM UNMODIFIED: DISCOURSES ON LIFE AND LAW 32, 37 (1987). Instead, MacKinnon proposed that legal feminists should begin to theorize about "dominance"-the power difference between men and women-such that feminist legal theory would begin to challenge women's subordination rather than women's formal inequality with men. Id. at 40-41.

6. See Angela P. Harris, Race and Essentialism in Feminist Legal Theory, 42 STAN. L. REV. 581, 586-88 (1990) (discussing need for "multivocal" feminist theory).

7. See Janet E. Halley, Reasoning About Sodomy: Act and Identity in and After Bowers v. Hardwick, 79 VA. L. REV. 1721, 1725 (1993) (criticizing feminist theory for failing to account for sexual orientation: "[H]eterosexuality may be inscribed as a norm in gender-based approaches."); Deborah L. Rhode, Feminism and the State, 107 HARV. L. REV. 1181, 1183 (1994) ("Any ethical and political framework adequate to challenge gender inequality must similarly challenge the other structures of subordination with which gender intersects."); Reva Siegel, Reasoning from the Body: A Historical Perspective on Abortion Regulation and Questions of Equal Protection, 44 STAN. L. REV. 261, 345 (1992) (arguing that feminist legal theory should recognize implicit antiwoman and antipoverty bias in many state-sponsored programs that purport to promote social welfare).

8. In fact, Fineman and Karpin published the collection as an explicit countermand to what Fineman calls feminists' "ambivalence" toward motherhood, both in general and as a scholarly topic (Fineman, Preface, p. ix). As evidence of this feminist ambivalence. Fineman describes having called for papers for a conference about motherhood in 1990 and having found that "almost all of the proposals received ... focused on abortion and birth control or on technology" (Fineman, Preface, p. ix). 
fact have children. ${ }^{9}$ Instead, the essays recognize motherhood as one role of many that women may take on.

Just as lesbian feminists, feminists of color, and feminists concerned with class differences have begun to show that feminist legal theory is flawed unless it accounts for the ways in which women are always already sexualized, raced, and classed, Fineman and Karpin's collection suggests that feminist legal theory also must account for "the persistence of traditional values that posit motherhood as evidence of womanhood" (Omolade, p. 279). Starting from the premise that "[a]11 women are socially defined as mothers or potential mothers" (Roberts, p. 229), several of the essays examine the disutility to women of this social definition. For example, Reva Siegel's argument that "abortion restrictions reflect stereotypical assumptions about women's roles" demonstrates how "status-based judgments about women" reflected in antiabortion rhetoric redound to the detriment of all women, regardless of whether they are in fact mothers. Stereotypical assumptions about women, Siegel shows, are neither less insidious nor less present elsewhere in women's lives by virtue of the stereotypes' visibility only in the context of motherhood (Siegel, pp. 64-65). Similarly, Marie Ashe argues that lawyers who uncritically accept social judgments about some women as bad mothers "participate in sustaining the legal structures of class division, of racial injustice, and of domestic violence that denigrate and oppress all women" (Ashe, p. 152).

Fineman and Karpin's collection, then, powerfully demonstrates that mothers' special legal concerns bear directly on the legal status of all women. As the 1970s and 1980s taught us, women risk concrete losses in law if feminist legal scholars do not attend to differences in women's social situations. ${ }^{10}$ For example, because courts have not recognized discrimination on the basis of motherhood as sex discrimination, ${ }^{11}$ mothers-and therefore women-lose legal protection against discrimination. Courts have extended this category bifurcation also to separate the specific concerns of women of color

9. For example, Fineman notes: "Motherhood is central to the social and legal definition of woman. A woman who does not have children will still, in the context of law and legal institutions, be treated as though she is (or may become) a mother" (Fineman, Preface, p.xii); cf. UAW v. Johnson Controls, Inc., 499 U.S. 187, 199 (1991) ("Respondent has chosen to treat all its female employees as potentially pregnant; that choice evinces discrimination on the basis of sex.").

10. As Katharine Bartlett puts it, "no version of gender equality can accomplish substantial social change unless it is familiar enough to take root in the very conditions of subordination it is expected to eliminate." Katharine T. Bartlett, Only Girls Wear Barrettes: Dress and Appearance Standards, Community Norms, and Workplace Equality, 92 MiCH. L. REV. 2541. 2546 (1994).

11. See, e.g., Phillips v. Martin Marietta Corp.. 400 U.S. 542, 544 (1971) (holding that employers may legitimately distinguish between women with parenting obligations and men if "[t]he existence of such conflicting family obligations [is] demonstrably more relevant to job performance for a woman than for a man"); Troupe v. May, 20 F.3d 734, 737-38 (7th Cir. 1994) (deciding that terminating an employee "because her employer did not expect her to return to work after her maternity leave" did not, of itself, constitute sex-based discrimination); see also Kathryn Abrams, Title VII and the Complex Female Subject, 92 MICH. L. REV. 2479, 2481 (1994). For criticism of such judicial reliance on apparently objective economic decisionmaking as mere reinforcement of ordinary prejudices, see Cass Sunstein, Three Civil Rights Fallacies, 79 CAL. L. REV. 751, 755-56 (1991). 
from those of women generally; instead, courts have insisted, for example, that women of color must bring "cause[s] of action for race discrimination, sex discrimination, or alternatively either, but not a combination of both."12

Fineman and Karpin's collection usefully fieshes out this disjunction in the legal and cultural treatment of women: Women are, by turns, presumed to be mothers and penalized for departing from the male norm of individualism (Kline, p. 124; Shalleck, pp. 321-22), or treated as individuals and penalized for their familial deviance from the individual model (Slaughter, pp. 73-75). Similarly, the collection's contributors realize that mothers are presumed to be heterosexual and are negated if they turn out to be lesbian (Harrison, p. 171), presumed to be white and discriminated against if they demonstrate themselves as raced (Roberts, p. 232; Kline, p. 118; Perales, p. 251), and presumed to be solvent and flatly excluded if they evince poverty (Fineman, p. 212).

In response to these contradictory images of women in law, the collection's authors write aware of what Fineman calls "crossover discourses": "the propensity for rhetorical images associated with being female in our culture, generated and perpetuated in one context, to spill over and define our understanding of women in other contexts" (Fineman, p. 207). The essays find no single relationship between women and motherhood, however. For example, Ruthann Robson's critique of the term mother challenges feminist legal theory to imagine the components behind the sum of its parts: When she wonders specifically "whether or not mother (or parent) is a category that can be lesbian as well as legal" (Robson, p. 115), ${ }^{13}$ she exhorts feminists to construct a legal theory responsive to lesbians as well as to heterosexual women. But Dorothy Roberts sees hope in the social use of the term mother, if only because parsing the term helps feminist legal scholars to recognize racism and patriarchy as "two interrelated, mutually supporting systems of domination [whose]

12. DeGraffenreid v. General Motors Assembly Div., 558 F.2d 480, 482 (8th Cir. 1977) (quoting DeGraffenreid v. General Motors Assembly Div., 413 F. Supp. 142, 143 (E.D. Mo. 1976)); see also Barbara J. Flagg, Fashioning a Title VII Remedy for Transparently White Subjective Decisionmaking, 104 YALE L.J. 2009, 2029 (1995) (discussing limits of Title VII doctrine as currently understood to "consist]] of the unconscious use of criteria of decision that are more strongly associated with whites than with nonwhites"); Peggie R. Smith, Separate Identities: Black Women, Work, and Title VII, 14 HARV. WOMEN'S L.J. 21, 22 (1991) ("Title VII has been of limited use for Black vomen due, in part, to the law's categorical approach to equality: racial ethnic groups in one category and women in another."). But cf. Jefferies v. Harris County Community Action Ass'n, 615 F.2d 1025, 1032 (5th Cir. 1980) (recognizing cause of action for compound race and sex discrimination).

Judges similarly resist viewing discrimination against lesbians as sex-based discrimination. See DeSantis v. Pacific Tel. \& Tel. Co., 608 F.2d 327, 329-30 (9th Cir. 1979) (concluding that "Title VII's prohibition of 'sex' discrimination applies only to discrimination on the basis of gender and should not be judicially extended to include sexual preference such as homosexuality"). But see Baehr v. Lewin, 852 P.2d 44, 59-61 (Haw. 1993) (explicitly upholding validity of same-sex marriages on sex discrimination grounds), the one case I find in which the sexual-orientation-discrimination-as-sex-discrimination argument prevails). See generally Andrew Koppelman, Why Discrimination Against Lesbians and Gay Men is Sex Discrimination, 69 N.Y.U. L. REV. 197, 202 (1994) ("[T] he prohibition of homosexuality preserves the polarities of gender on which rests the subordination of women.").

13. Kate Harrison contends that "the lesbian who becomes a mother... will be perceived to be heterosexual, purely as a result of the fact that she is a mother" (Harrison, p.171). 
relationship is essential to understanding the subordination of all women" (Roberts, p. 224). ${ }^{14}$ And Marty Slaughter and Joanna Weinberg share Roberts's affinity for the term mother, not because they examine race but because they use mother as a yardstick of care or nurturance (Slaughter, p. 73; Weinberg, p. 328). Nonetheless, Slaughter and Weinberg reach divergent conclusions about the necessity of women's relationship to that care: Slaughter chafes against legal presumptions of women's caregiving function as precluding women's full participation in the labor market (Slaughter, pp. 74-75); Weinberg accepts the presumption but calls for a reciprocal (motherto-child and child-to-mother) understanding of that care (Weinberg, p. 335).

The recognition in these essays not only of the antiwoman, but also of the antilesbian, racist, and classist judgments implicit in social parenting policies illustrates how feminist legal theorizing in the 1990s self-consciously responds to a greater variety of women's concerns. And as a group, the essays in this collection move far toward such a responsive theory or theories: The essays offer detailed prescriptions for putting intersectional feminist conceptions of motherhood into practice and so demonstrate the difference this intersectionality may make in women's lives. For example, Ashe calls for more sympathetic feminist responses to "bad" mothers, arguing that these mothers' deviance may differ only from unrealistic standards of true motherhood rather than from some universalist notion of goodness (Ashe, p. 149). ${ }^{15}$ And Siegel supports Ashe's claim that negative social perceptions of mothers' behavior-and particularly that of the poor mothers of color whom Ashe describes representing in her law school clinic-may in fact reflect biases irrelevant to the purportedly deviant behavior: "Public authorities may focus their regulatory efforts on poor women of color because their lives diverge most sharply from the white, middle-class norms that define 'good' motherhood in this society" (Siegel, pp. 56-57). ${ }^{16}$ Finally, writing as if in direct response to Ashe's and Siegel's illuminations of social biases, Slaughter demonstrates the economic marginalization of mothers as a trope for

14. Nina Perales also notes that "compound discrimination [racism and sexism] is responsible for the urge felt by many people to restrict and dominate the practice of motherhood by [African American and Latina] women" (Perales, p. 251); similarly, Siegel parses "antimaternalist and race-essentialist tendencies" in historical pro-choice arguments (Siegel, p. 69).

15. Ashe notes that representing an accused mother may "remind[] us that while caring for children is never easy, being poor makes it harder; experiencing racism makes it harder; experiencing homophobia makes it harder; and experiencing the fear of violence within one's own household makes it harder still" (Ashe, p. 149).

16. See also Siegel, supra note 7, at 363-68 (parsing putatively gender-neutral explanations for implicit gender bias); cf. Austin Sarat, “. . . The Law Is All Over": Power, Resistance and the Legal Consciousness of the Welfare Poor, 2 YALE J.L. \& HUMAN. 343, 344 (1990) (noting that public authorities do in fact regulate poor people more intensively than other groups). 
antiwoman bias inherent in the structure of U.S. labor markets (Slaughter, p. 73). ${ }^{17}$ According to Slaughter, the current labor market assumes that families will have dual incomes and that women will raise children; because of these assumptions, all women's - and not just mothers'-pay has yet to reach levels commensurate with men's (Slaughter, pp. 74, 82). ${ }^{18}$ Slaughter argues that "[a]nything that constructs or favors men as Breadwinners also constructs or favors women as Mothers"-and so she challenges the ways in which law "both constitutes and legitimates" women's role as mothers rather than as employees in the labor market (Slaughter, p. 75). ${ }^{19}$

These intersectional analyses reveal that apparently objective or benign social parenting policies, such as attempts to eradicate child abuse or family poverty, may in fact reinforce social biases against particular groups to which women belong or against all women generally. ${ }^{20}$ Such revelation of bias should lay groundwork for reimagining feminist legal theorizing and restructuring feminist litigation strategies. In fact, the essays in the collection, not content merely with excavating the socially and legally inequitable treatment of women, offer preliminary-and varied-solutions to the problems on which they focus. The variousness of the authors' solutions, coupled with the multiplicity of their subject matter, constitutes one of the collection's signal strengths: By offering several perspectives on one topic, the essays in Fineman and Karpin's collection engage seriously the feminist and legal implications of our society's treatment of motherhood. In the process, these essays offer useful ways to enhance feminist legal theorizing. With fresh insight, attention to women's diverse characteristics, and innovative suggestions for reform, these essays enrich the dialogue of feminist legal scholarship.

- Catherine E. Lhamon

17. See also Mary Jane Mossman, who cites surveys of Canadian lawyers as evidence that private law practice depends on "hidden assumption[s] about the availability of full-time domestic labor to support the activities of lawyers in the workforce" (Mossman, pp. 291-92).

18. See also Sylvia Nasar, Women's Progress Stalled? Just Not So, N.Y. TIMES, Oct. 18, 1992, § 3 , at 1 (noting that women in United States earned $72 \notin$ for each dollar of men's earnings in 1990).

19. See also Rhode, supra note 7, at 1183 ("Government support for traditional gender roles perpetuates class oppression by enabling employers to pay less than the full cost of maintaining a labor force and by relegating women to a reserve army of provisional workers."); Vicki Schultz, Telling Stories About Women and Work: Judicial Interpretations of Sex Segregation in the Workplace in Title VII Cases Raising the Lack of Interest Argument, 103 HARV. L. REV. 1749, 1756 (1990) ("[C]ourts have assumed that women's aspirations and identities as workers are shaped exclusively in private realms that are independent of and prior to the workworld. ... [And so] courts have missed the ways in which employers contribute to creating women workers in their images of who 'women' are supposed to be."); Joan C. Williams, Deconstructing Gender, 87 MiCH. L. REV. 797, 814 (1989) (arguing that EEOC v. Sears, Roebuck \& Co., 628 F. Supp. 1264 (N.D. Ill. 1986), aff'd, 839 F.2d 302 (7th Cir. 1988), "establishes a legal assumption that all women fit gender stereotypes and imposes on plaintiffs a burden to disprove that assumption as part of their prima facie case").

20. For an analogous denionstration of bias, see Dorothy E. Roberts, Punishing Drug Addicts Who Have Babies: Women of Color, Equity, and the Right of Privacy, 104 HARv. L. REv. 1419, 1442-44 (1991) (recognizing connection between antirace and antipoverty bias inherent in prosecution of drug-addicted pregnant women). 